\title{
Uji Adaptasi dan Seleksi Varietas Partisipatif terhadap Galur-Galur Padi Toleran Rendaman dan Kekeringan di Lahan Rawa Lebak
}

\author{
Adaptation and Participatory Varietal Selection of Submergence \\ and Drought Tolerant Rice at Freshwater Swamp \\ Indrastuti Apri Rumanti ${ }^{1 *}$, Koesrini², Hendri Sosiawan², dan Yanti Rina ${ }^{2}$ \\ ${ }^{1}$ Balai Besar Penelitian Tanaman Padi \\ Jl. Raya Sukamandi No. 9, Subang, Jawa Barat, Indonesia \\ ${ }^{2}$ Balai Penelitian Pertanian Lahan Rawa \\ J1. Kebun Karet, Loktabat Utara Kotak Pos 31, Banjarbaru, Kalimantan Selatan, Indonesia
}

Diterima 13 Juli 2020/Disetujui 7 Agustus 2020

\begin{abstract}
The role of high yielding varieties along with fertilization and water management for increasing rice productivity is essential. Therefore, the efforts to increase productivity in the middle freshwater swamp are carried out using high yielding varieties with fertilization and water management called mini polder. The mother trial was conducted to introduce 10 rice genotypes, with optimal fertilizer and water management. It has been carried out in Hulu Sungai Utara District, South Kalimantan Province. The research was following a randomized block design with three replications. The baby trials were carried out in 10 farmer fields. Assessment of genotypes was carried out using questionnaires and participatory selection methods. The results showed that the yield and yield components of genotypes grown in the mother trial were better than baby trials. Both assessment of genotypes produced fairly consistent assessments. There were three varieties preferred by most respondents, namely Inpara 3, Tapus and Inpara 8 Agritan. Some characters such as plant vigor, number of productive tillers, grain shape and color, maturity, and disease resistance were important in the development of rice varieties in swamp land.
\end{abstract}

Keywords: high yielding varieties, freshwater swamp, preference, participatory selection

\section{ABSTRAK}

Peran varietas unggul bersama pemupukan dan tata air terhadap peningkatan produktivitas sangat tinggi. Oleh karena itu upaya peningkatan produktivitas padi di lahan rawa lebak tengahan dilakukan dengan mengintegrasikan varietas unggul dengan pemupukan dan tata kelola air. Percobaan induk berupa pengenalan 10 genotipe unggul padi, dengan pemupukan optimal serta tata kelola air memanfaatkan mini polder telah dilakukan di Kabupaten Hulu Sungai Utara, Provinsi Kalimantan Selatan. Rancangan yang digunakan adalah rancangan acak kelompok dengan tiga ulangan. Percobaan anak dilakukan di 10 lahan petani dengan teknik budidaya sesuai kebiasaan petani. Penilaian terhadap genotipe dilakukan menggunakan kuisioner dan metode seleksi partisipatif. Hasil penelitian menunjukkan bahwa komponen hasil dan bobot hasil genotipe yang ditanam di percobaan induk lebih baik dibandingkan di percobaan anak. Kedua metode penilaian genotipe, menghasilkan penilaian yang cukup konsisten. Tiga varietas disukai oleh sebagian besar responden, yaitu Inpara 3, Tapus, dan Inpara 8 Agritan. Beberapa aspek yang perlu diperhatikan dalam perakitan dan pengembangan varietas padi di lahan rawa lebak antara lain vigor tanaman, jumlah anakan produktif, bentuk dan warna gabah, umur tanaman dan ketahanan terhadap penyakit.

Kata kunci: preferensi, rawa lebak, seleksi partisipatif, varietas unggul

\section{PENDAHULUAN}

Program perakitan varietas unggul baru sangat relevan untuk menunjang keberhasilan sistem budidaya oleh petani. Varietas unggul merupakan komponen utama pada paket

*Penulis untuk korespondensi. e-mail: indrastuti.apri@gmail.com teknologi terpadu, yang dapat digunakan secara mudah dan murah oleh petani, karena dapat menekan resiko kehilangan akibat cekaman lingkungan abiotik maupun biotik. Oleh karena itu, varietas unggul akan mampu menambah nilai positif ketersediaan pangan (Shelton dan Tracy, 2016).

Petani di lahan rawa lebak bercocok tanam di akhir musim hujan, sehingga tanaman padi akan dihadapkan pada dua cekaman selama pertumbuhannya, yaitu cekaman 
rendaman saat fase vegetatif, dan kekeringan saat memasuki fase generatif. Kejadian El Niño yang menginduksi kekeringan menyebabkan genangan air di lahan rawa lebak semakin surut sehingga areal yang dapat ditanami bertambah luasnya, terutama lahan lebak dalam dan tengahan. Namun selain kekeringan, perlu diwaspadai juga adanya ancaman keracunan $\mathrm{Al}$, peningkatan salinitas dan hama penyakit (Maftu'ah et al., 2016). Bahkan pada lahan lebak dengan gambut cukup tebal, dapat terjadi irreversible drying yang dapat meningkatkan kerentanan terhadap kebakaran, serta meningkatkan emisi karbon (Dariah et al., 2013).

Dilahan lebak tengah tengahan, genangan air terjadi dalam periode 3-6 bulan. Kedalaman permukaan air tanah maksimum di lahan lebak tengahan mencapai $-50 \mathrm{~cm}$ yang terjadi pada bulan Agustus, sedangkan genangan maksimum terjadi pada bulan Desember-Januari dengan lamanya periode tergenang hingga 6-9 bulan (Waluyo et al., 2008). Luas genangan relatif stabil selama Januari hingga April (Trinugoho dan Mawardi, 2017). Oleh karena itu, diperlukan varietas unggul padi yang adaptif terhadap kedua cekaman dan infrastruktur mini polder untuk pengelolaan air di lahan-lahan tersebut. Mini-polder merupakan infrastruktur pengelolaan air yang terdiri atas tanggul keliling, saluran utama/sekunder dan tersier, pintu-pintu air, dan pompa besar (Noor et al., 2019), yang digunakan untuk mengelola air seluas 200-500 Ha.

Salah satu kendala upaya diseminasi varietas baru adalah beragamnya preferensi petani terhadap suatu varietas, baik dari morfologi tanaman maupun mutu beras yang dihasilkan (Singh et al., 2013). Preferensi yang sangat beragam antar daerah, bahkan antar petani membutuhkan ketersediaan varietas unggul yang lebih beragam dari pemulia.

Pada rangkaian program pemuliaan dan diseminasi, seleksi galur dan varietas secara partisipatif (participatory varietal selection/PVS) dikembangkan untuk meningkatkan keterlibatan petani dalam pemilihan calon varietas yang akan dilepas untuk mempercepat proses adopsi varietas tersebut nantinya. Program ini memberikan ruang identifikasi dan pemecahan permasalahan lingkungan heterogen. Selain itu identifikasi genotipe superior yang mampu bertahan pada tekanan lingkungan dapat dilakukan (Aristya, 2017), baik oleh petani, pemulia, penyuluh pertanian maupun pedagang. Model PVS dilaporkan mempercepat adopsi varietas padi toleran rendaman di sejumlah negara Asia Tenggara (Manzanilla et al., 2011), dilakukan dalam bentuk percobaan on farm induk dan anak percobaan (Hairmansis et al., 2015). Evaluasi terhadap persepsi dan preferensi petani dikumpulkan melalui kuesioner sederhana dan diskusi kelompok yang terfokus, serta analisis statistik yang sesuai untuk data kuantitatif dan kualitatif persepsi (Bhatta et al., 2006). Melalui pendekatan ini diharapkan varietas yang dilepas atau didiseminasikan sesuai dengan preferensi petani, sehingga lebih cepat diterima dan diadopsi. Terlebih lagi, petani di daerah rawa lebak sebagian besar adalah petani subsistem dengan penggunaan input yang minimal, termasuk penggunaan varietas unggul yang berlabel.

Tujuan penelitian ini adalah mempelajari penampilan morfologi dan bobot hasil genotipe padi rawa di lahan rawa serta mengetahui preferensi petani, penyuluh dan pedagang padi terhadap galur harapan dan varietas padi rawa melalui metode participatory varietal selection (PVS).

\section{BAHAN DAN METODE}

Verifikasi adaptasi varietas dan galur padi rawa dilaksanakan di lahan rawa lebak tengahan di Desa Hambuku Raya, Kecamatan Sungai Pandan, Kabupaten Hulu Sungai Utara, Provinsi Kalimantan Selatan pada MH 2018/19, yaitu Oktober 2018 hingga Januari 2019. Curah hujan berturut-turut sebesar $94 \mathrm{~mm}, 208 \mathrm{~mm}, 351 \mathrm{~mm}$ dan $360 \mathrm{~mm}$ dengan curah hujan total selama 4 bulan mencapai 1013 mm (BPS, 2019; BPS, 2020). Tinggi genangan selama percobaan berlangsung berkisar antara $30-50 \mathrm{~cm}$. Kegiatan meliputi percobaan induk (mother trial) dan percobaan anak (baby trial).

Pada kegiatan mother trial, 10 genotipe (Tabel 1) ditanam mengikuti rancangan acak kelompok, dengan tiga ulangan. Masing-masing genotipe ditanam pada plot ukuran $4 \mathrm{~m}$ x $5 \mathrm{~m}$, dengan jarak tanam $25 \mathrm{~cm} \times 25 \mathrm{~cm}$, menggunakan 2-3 bibit tiap lubang tanam, umur bibit 25 hari setelah semai (HSS). Percobaan skala petani (baby trial) dilaksanakan dengan melibatkan 10 petani yang memiliki lahan disekeliling mother trial. Masing-masing genotipe ditanam seluas $\pm 100 \mathrm{~m}^{2}$ tanpa ulangan, pemeliharaan disesuaikan dengan kebiasaan petani.

Dosis pupuk untuk percobaan induk ditentukan menggunakan bantuan perangkat uji tanah rawa (PUTR), yaitu $130 \mathrm{~kg} \mathrm{ha}^{-1}$ Urea dan Phonska (N:P:K=15:15:15) sebanyak $200 \mathrm{~kg} \mathrm{ha}^{-1}$, sedangkan pada percobaan anak digunakan dosis $50 \mathrm{~kg} \mathrm{ha}^{-1}$ Urea dan $100 \mathrm{~kg} \mathrm{ha}^{-1}$ Phonska. Trap Barrier System (TBS), sanitasi dan bubu perangkap diaplikasikan untuk antisipasi gangguan tikus. Pengamatan terhadap seluruh genotipe dilakukan terhadap sejumlah karakter morfologi, komponen hasil dan hasil.

Data preferensi dikumpulkan dengan pendekatan analisis preferensi dan Participatory Varietal Selection (PVS). Tiga puluh responden akan menilai 10 genotipe yang ditanam pada percobaan induk. Pada seleksi partisipatif (PVS), masing-masing responden harus memilih dua genotipe yang disukai dan dua genotipe yang tidak disukai. Pemilihan dilakukan menggunakan kartu yang telah diberi tanda khusus. Masing-masing kartu dimasukan ke dalam kantong yang tersedia di depan setiap genotipe. Untuk menjaga obyektivitas responden, maka nama genotipe ditutup. Selanjutnya dilakukan pengisian kuisioner sederhana yang berisi parameter dan karakter yang disukai petani terhadap tanaman padi yang telah diamati. Kegiatan ini diakhiri dengan diskusi dengan seluruh responden mengenai alasan pemilihan genotipe terbaik dan kekurangan dari genotipe yang tidak disukai.

\section{Metode Analisis}

Nilai skor preferensi dihitung dari bobot dikali jumlah petani untuk setiap varietas. Preferensi total dari setiap genotipe merupakan skor rata-rata dari semua karakter yang dimiliki oleh varietas/galur. Preferensi petani terhadap 
Tabel 1. Karakteristik galur dan varietas yang digunakan dalam uji adaptasi dan preferensi, di Desa Hambuku Raya, Kabupaten Hulu Sungai Utara, Provinsi Kalimantan Selatan, MH 2018/19

\begin{tabular}{llcll}
\hline No. & Galur/Varietas & Kadar amilosa $(\%)$ & Tekstur nasi & \multicolumn{1}{c}{ Keunggulan/Spesifikasi } \\
\hline 1 & Inpara 3 & 28.6 & Pera & Toleran genangan (long-term flooding) \\
2 & Tapus & 26.3 & Pera & Toleran genangan (long-term flooding) \\
3 & Inpara 8 & 28.5 & Pera & Toleran rendaman saat vegetatif (submergence) \\
4 & Inpari 30 & 22.4 & Pulen & Toleran rendaman saat vegetatif (submergence) \\
5 & Inpari 22 & 21.9 & Pulen & Tahan penyakit blast daun \\
6 & Inpari 42 & 18.8 & Pulen & Tahan penyakit blast daun \\
7 & Inpari 43 & 18.9 & Pulen & Tahan penyakit blast daun \\
8 & B13926E-KA-1 & 23.0 & Sedang & Toleran genangan dan kekeringan \\
9 & B14366E-KY-3 & 22.7 & Pulen & Toleran genangan dan kekeringan \\
10 & IR11T230 & 22.4 & Pulen & Toleran genangan dan kekeringan \\
\hline
\end{tabular}

Sumber: Balai Besar Penelitian Tanaman Padi

karakter tipe tanaman, tinggi tanaman, jumlah anakan produktif, bentuk, ukuran dan warna gabah, serangan hama/ penyakit, vigor serta umur tanaman dihitung dari rata-rata semua nilai skor untuk semua genotipe yang diuji. Data preferensi petani didistribusikan pada kelas yang berbeda. Pemberian skor menggunakan skala Likert dengan lima kriteria (Darsani dan Koesrini, 2018; Tabel 2). Penilaian pada PVS, nilai preferensi varietas masing-masing galur dan varietas yang diuji diperoleh dengan menghitung jumlah kartu yang berada dalam kantong kertas, menggunakan persamaan yang diberikan oleh Paris et al. (2011).

\section{HASIL DAN PEMBAHASAN}

Keragaan Komponen Hasil dan Bobot Panen Galur dan Varietas

Sebelum dilakukan analisis sidik ragam, data dari percobaan anak dan percobaan induk diuji sebaran normalnya menggunakan uji kenormalan Anderson Darling (Mattjik dan Sumertajaya 2002). Data yang dianalisis adalah data tiga ulangan dari percobaan induk. Gambar 1 menunjukkan plot data tersebut berada di sekitar garis lurus. Hal ini menunjukkan bahwa data hasil gabah menyebar normal. Uji homogenitas juga dilakukan menggunakan metode Bartlett. Hasil uji menunjukkan bahwa data menyebar normal untuk semua karakter yang diamati. Homogenitas data ditunjukkan oleh sebaran data yang berada di sekitar garis lurus, seperti yang ditunjukkan oleh Gambar 1 dan nilai chi square yang lebih besar dibandingkan nilai tabel chi square (Tabel 3). Gambar 1 menunjukkan hasil uji homogenitas Bartlett untuk karakter bobot hasil per hektar. Tabel 3 dan Gambar 1 menunjukkan bahwa data dapat dilanjutkan untuk di analisa ragam dan uji lanjut.

Sepuluh genotipe menunjukkan variasi di seluruh karakter yang diamati di lahan rawa lebak tengahan (Tabel 4). Tinggi tanaman bervariasi dari $90.2 \mathrm{~cm}$ (Inpari 43) hingga $140 \mathrm{~cm}$ yang ditunjukkan oleh varietas Inpara 8 Agritan. Sasmita et al. (2019) menyampaikan bahwa Inpara 8 Agritan memiliki tinggi tanaman berkisar $107 \mathrm{~cm}$. Tinggi tanaman Inpara 8 Agritan yang lebih tinggi ini diduga karena kondisi lahan yang sangat subur dan kondisinya basah sedari vegetatif hingga panen, karena peningkatan tinggi tanaman juga terjadi pada genotype lainnya lainnya.

Seluruh varietas dan galur yang diuji juga memiliki jumlah anakan yang cukup banyak, berkisar antara 1929 rumpun. Koesrini et al. (2018) menyampaikan bahwa tingkat kesuburan tanah berpengaruh terhadap pembentukan anakan dan malai tanaman. Pada fase tersebut, tanaman memerlukan hara makro dan hara mikro yang cukup besar untuk membentuk anakan, malai, dan pengisian gabah.

Tabel 2. Interval preferensi petani terhadap morfologi tanaman dan gabah beberapa varietas dan galur padi di lahan rawa lebak

\begin{tabular}{llccc}
\hline Interval skor $(\%)$ & \multicolumn{1}{c}{ Preferensi } & Bobot $(\%)$ & Jumlah petani (orang) & Nilai skor (\%) \\
\hline $84.01-100$ & Sangat suka & 20 & $\mathrm{n}$ & $\mathrm{n} \times$ bobot \\
$68.01-84.00$ & Suka & 20 & $\mathrm{n}$ & $\mathrm{n} \times$ bobot \\
$52.01-68.00$ & Cukup suka & 20 & $\mathrm{n}$ & $\mathrm{n} \times$ bobot \\
$36.01-52.00$ & Tidak suka & 20 & $\mathrm{n}$ & $\mathrm{n}$ bobot \\
$20.00-36.00$ & Sangat tidak suka & 20 & $\mathrm{n}$ & $\mathrm{n}$ bobot \\
\hline
\end{tabular}



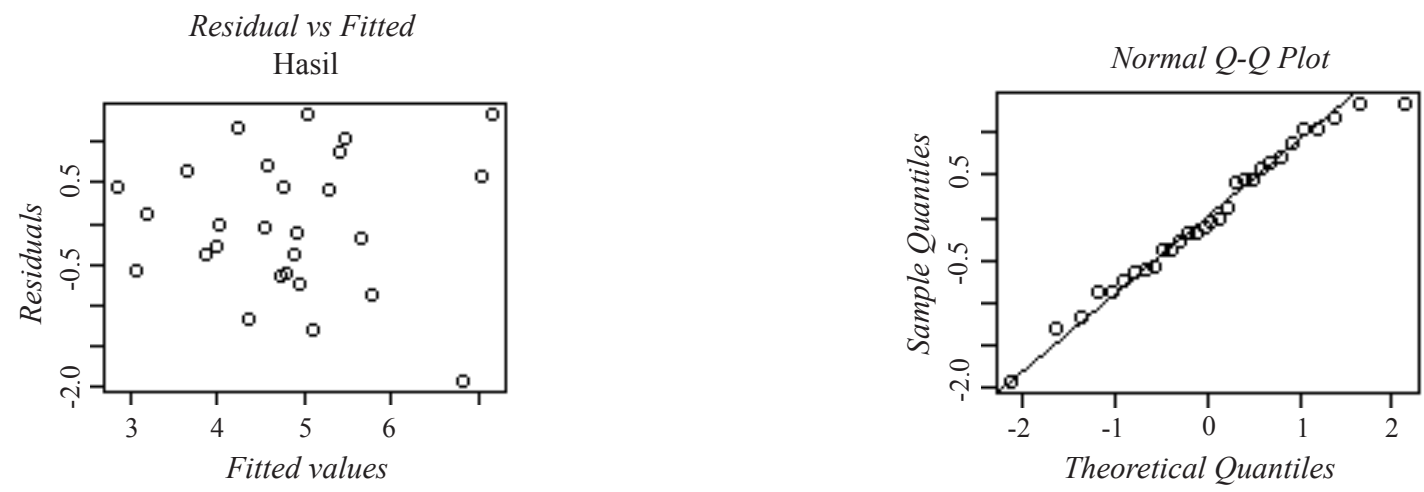

Gambar 1. Uji homogenitas Barlett untuk karakter bobot hasil per hektar

Bobot hasil berbeda nyata antar genotipe (Tabel 6). Bobot hasil tertinggi di hasilkan oleh Inpara 8 Agritan, yang mencapai 7 ton $\mathrm{ha}^{-1}$. Varietas ini berhasil melampaui potensi hasilnya sebesar 6 ton ha-1 di lahan lebak tengahan. Varietas ini juga memiliki daun bendera yang tegak, sehingga ideal untuk menerima cahaya matahari dan akhirnya menghasilkan biomassa yang cukup tinggi. Wahyuti et al. (2013) menyampaikan bahwa panjang dan lebar daun adalah faktor yang berhubungan dengan struktur kanopi. Bentuk kanopi berperan penting untuk menangkap radiasi matahari. Koesrini et al. (2017) menyampaikan bahwa daun bendera tegak memungkinkan penetrasi dan distribusi cahaya lebih besar sampai ke bagian bawah dan merata, sehingga meningkatkan fotosintesis $20 \%$ lebih tinggi daripada daun terkulai pada kondisi indeks luas daun tinggi. Karakter bobot hasil merupakan salah satu faktor penting dalam menentukan keunggulan suatu varietas. Beberapa varietas yang menghasilkan bobot gabah panen yang cukup baik, antara lain Inpari 30, Inpari 42, Inpari 22 dan Inpara 3. Varietas Inpari 43 Agritan kurang adaptif di lahan rawa lebak, sehingga bobot gabah panennya rendah. Terdapat satu galur yang relatif lebih unggul di bandingkan dua galur lainnya (Tabel4), yaitu IR11T230 yang memiliki keunggulan toleran rendaman pada fase vegetatif dan kekeringan pada fase generatif. Genotipe ini memiliki kemampuan untuk mempertahankan vigor, tinggi tanaman, jumlah anakan produktif pada saat cekaman. Genotipe toleran rendaman akan berhenti tumbuh saat terjadi rendaman di fase vegetatif, seluruh cadangan karbohidrat akan disimpan

Tabel 3. Uji homogenitas data menggunakan uji Bartlett

\begin{tabular}{lcc}
\hline Karakter & $\begin{array}{c}\text { Nilai } \\
\text { Chi square }\end{array}$ & $\operatorname{Pr}(>$ Chisq $)$ \\
\hline Tinggi tanaman & 19.87 & 0.02 \\
Jumlah anakan & 11.94 & 0.22 \\
Bobot brangkasan basah & 12.98 & 0.16 \\
Bobot brangkasan kering & 11.26 & 0.26 \\
Panjang malai & 10.20 & 0.33 \\
Bobot hasil per hektar & 5.53 & 0.79 \\
\hline
\end{tabular}

untuk pemulihan disaat air surut. Umur panen genotipe ini juga relatif tidak mengalami penundaan yang terlalu lama, diduga karena mampu memecah karbohidrat dan mendistribusikannya ke seluruh bagian tanaman sehingga pulih dari cekaman dengan lebih cepat. Wening et al. (2019) juga telah mengidentifikasi IR11T230 sebagai genotipe toleran karena memiliki penundaan umur berbunga dan panen yang lebih pendek dibandingkan genotipe sensitif saat cekaman rendaman, dan mampu mempertahankan vigor, hasil dan komponen hasilnya relatif dibandingkan pada kondisi normal.

Tampilan genotipe saat dibudidayakan dengan cara petani setempat terlihat beragam, terutama pada karakter jumlah anakan per rumpun, bobot brangkasan dan bobot hasil (Tabel 6). Jumlah anakan yang terbentuk, relatif lebih sedikit dibandingkan dengan budidaya optimal pada percobaan induk (Tabel 3). Begitu juga bobot brangkasan basah, menunjukkan bahwa biomasa yang terbentuk lebih rendah dibandingkan bobot brangkasan di percobaan induk. Pada karakter bobot hasil panen, terdapat tiga varietas dan satu galur yang memiliki bobot panen di atas $5 \mathrm{t} \mathrm{ha}^{-1}$. Varietas dan galur tersebut berturut-turut dari hasil tertinggi, antara lain Inpara 8 Agritan, Inpari 30 Ciherang Sub1, Inpara 3 dan B14366E-KY-3. Keempat genotipe tersebut memiliki toleransi terhadap cekaman rendaman, yang dikendalikan oleh gen Sub1 yang terekpresi saat tercekam rendaman (Rumanti et al., 2016) dan genangan hingga 60 $\mathrm{cm}$ (Sitaresmi et al., 2019). Peng (2017) menyampaikan bahwa besarnya senjang antara potensi hasil dengan bobot aktual di petani, perlu ditekan dengan perbaikan budidaya tanaman. Kaitannya dengan perubahan iklim global, maka perlu pendekatan khusus sebagai salah satu teknik adaptasi terhadap adanya perubahan iklim tersebut. Pendekatan tersebut sering disebut sebagai climate-smart crop management.

\section{Seleksi Varietas/Galur secara Partisipatif (PVS)}

Hasil seleksi partisipatif menunjukkan bahwa responden sebagian besar menyukai varietas Inpara 8 Agritan, Tapus, Inpara 3 dan Inpari 22 secara berturutturut (Tabel 7). Sebanyak 56.7\% responden menyatakan 
Tabel 4. Karakter tinggi tanaman, jumlah anakan produktif, umur panen dan bobot brangkasan 10 genotipe di lahan rawa lebak pada percobaan induk (mother trial), Desa Hambuku Raya, Kabupaten Hulu Sungai Utara, Provinsi Kalimantan Selatan, MH 2018/19

\begin{tabular}{lcccccc}
\hline Genotipe & $\begin{array}{c}\text { Tinggi tanaman } \\
(\mathrm{cm})\end{array}$ & $\begin{array}{c}\text { Jumlah anakan } \\
\text { produktif }\end{array}$ & $\begin{array}{c}\text { Toleransi } \\
\text { terhadap } \\
\text { rendaman }\end{array}$ & $\begin{array}{c}\text { Umur } \\
\text { panen } \\
(\mathrm{HSS})\end{array}$ & $\begin{array}{c}\text { Bobot } \\
\text { brangkasan basah } \\
\text { per rumpun }(\mathrm{g})\end{array}$ & $\begin{array}{c}\text { Bobot brangkasan } \\
\text { kering per rumpun } \\
(\mathrm{g})\end{array}$ \\
\hline Inpara 3 & $132.5 \mathrm{ab}$ & $22.8 \mathrm{bc}$ & 3 & $127 \mathrm{a}$ & $319.3 \mathrm{ab}$ & $120.9 \mathrm{abc}$ \\
Inpara 8 & $140.2 \mathrm{a}$ & $23.1 \mathrm{bc}$ & 1 & $115 \mathrm{~b}$ & $316.7 \mathrm{ab}$ & $130.5 \mathrm{ab}$ \\
Tapus & $119.3 \mathrm{~cd}$ & $24.4 \mathrm{ab}$ & 1 & $114 \mathrm{~b}$ & $330.0 \mathrm{ab}$ & $85.3 \mathrm{bcd}$ \\
Inpari 42 & $109.3 \mathrm{~d}$ & $23.2 \mathrm{bc}$ & 3 & $112 \mathrm{~b}$ & $234.1 \mathrm{~cd}$ & $79.9 \mathrm{bcd}$ \\
Inpari 22 & $107.7 \mathrm{~d}$ & $25.1 \mathrm{ab}$ & 5 & $118 \mathrm{~b}$ & $251.7 \mathrm{bc}$ & $85.7 \mathrm{bcd}$ \\
Inpari 30 & $115.0 \mathrm{~cd}$ & $24.9 \mathrm{ab}$ & 3 & $111 \mathrm{~b}$ & $281.2 \mathrm{abc}$ & $78.9 \mathrm{~cd}$ \\
Inpari 43 & $90.2 \mathrm{e}$ & $28.6 \mathrm{a}$ & 5 & $111 \mathrm{~b}$ & $232.4 \mathrm{~cd}$ & $74.9 \mathrm{~cd}$ \\
IR11T230 & $118.5 \mathrm{~cd}$ & $26.8 \mathrm{ab}$ & 1 & $114 \mathrm{~b}$ & $224.1 \mathrm{~cd}$ & $64.7 \mathrm{~d}$ \\
B14366E-KY-3 & $118.0 \mathrm{~cd}$ & $18.6 \mathrm{c}$ & 3 & $117 \mathrm{~b}$ & $333.9 \mathrm{a}$ & $153.3 \mathrm{a}$ \\
B13926E-KA-1 & $125.2 \mathrm{bc}$ & $24.8 \mathrm{ab}$ & 3 & $114 \mathrm{~b}$ & $160.5 \mathrm{~d}$ & $99.3 \mathrm{bcd}$ \\
\hline Rata-rata & 117.6 & 24.2 & - & 115.3 & 268.4 & 97.4 \\
\hline KK(\%) & 5.3 & 10.7 & - & 4.5 & 15.9 & 17.2 \\
\hline
\end{tabular}

Keterangan: Angka yang diikuti huruf yang sama tidak berbeda nyata pada uji lanjut BNT taraf 5\%, KK = koefisien keragaman. Data toleransi terhadap genangan tidak diikutkan dalam analisa. Skor toleransi rendaman, 1 = toleran, 3 agak toleran, 5 agak rentan, 7 rentan, 9 sangat rentan

kesukaannya terhadap Inpara 8 Agritan yang menghasilkan bobot hasil tertinggi ( 7.0 ton $\mathrm{ha}^{-1}$ ) dan menghasilkan nilai preferensi sebesar 0.40 (Tabel 7). Inpara 8 Agritan disukai karena umurnya yang pendek, proses pengisian biji cepat, tidak disukai walang sangit, bentuk gabah dan beras medium, gabah tipis sehingga rendemen tinggi, daun bersih sebagai indikasi ketahanannya terhadap hawar daun bakteri dan blast daun yang banyak dijumpai di lokasi. Hasil pengujian Rumanti et al. (2016), Inpara 8 Agritan memiliki ketahanan terhadap blast daun dan 3 patotipe hawar daun bakteri. Kedua penyakit ini sering dijumpai di lahan-lahan rawa.

Pilihan berikutnya adalah varietas Tapus, yang disukai oleh $40 \%$ responden dan nilai preferensi sebesar 0.20 (Tabel 7). Tapus merupakan varietas lamayang dilepas karenaadaptif pada kondisi genangan dan memiliki kemampuan tumbuh cepat mengikuti tinggi muka air tanah hingga maksimum $150 \mathrm{~cm}$ (Ningsih, 2011). Varietas ini disukai karena bentuk

Tabel 5. Keragaan hasil dan komponen hasil 10 galur/varietas di lahan rawa lebak pada percobaan induk (mother trial), Desa Hambuku Raya, Kabupaten Hulu Sungai Utara, Provinsi Kalimantan Selatan, MH 2018/19

\begin{tabular}{|c|c|c|c|c|}
\hline Genotipe & Panjang malai (cm) & Gabah isi per malai & Bobot 1000 butir (g) & Hasil (ton $\left.\mathrm{ha}^{-1}\right)$ \\
\hline Inpara 3 & $23.2 \mathrm{bcde}$ & $99.3 b c$ & 31.3 & $4.8 \mathrm{bc}$ \\
\hline Inpara 8 & $26.2 \mathrm{ab}$ & $143.8 \mathrm{a}$ & 28.4 & $7.0 \mathrm{a}$ \\
\hline Tapus & $26.9 \mathrm{a}$ & $107.8 \mathrm{~b}$ & 22.9 & $4.9 \mathrm{bc}$ \\
\hline Inpari 42 & 24.6abcd & $109.5 \mathrm{~b}$ & 21.9 & $5.3 \mathrm{ab}$ \\
\hline Inpari 22 & 22.7 cde & $108.2 b$ & 25.7 & $5.6 \mathrm{ab}$ \\
\hline Inpari 30 & $22.1 \mathrm{de}$ & $109.2 b$ & 26.8 & $5.8 \mathrm{ab}$ \\
\hline Inpari 43 & $19.9 \mathrm{e}$ & $91.3 \mathrm{bc}$ & 19.3 & $3.8 \mathrm{bc}$ \\
\hline IR11T230 & $21.7 \mathrm{de}$ & $97.1 \mathrm{bc}$ & 23.2 & $4.7 \mathrm{bc}$ \\
\hline B14366E-KY-3 & $26.3 \mathrm{ab}$ & $81.2 \mathrm{c}$ & 25.3 & $3.0 \mathrm{c}$ \\
\hline B13926E-KA-1 & $25.6 \mathrm{abc}$ & $104.3 \mathrm{bc}$ & 21.9 & $3.5 \mathrm{bc}$ \\
\hline Rata-rata & 23.9 & 105.2 & 24.7 & 4.9 \\
\hline $\mathrm{KK}(\%)$ & 7.3 & 14.7 & 12.7 & 15.2 \\
\hline
\end{tabular}

Keterangan: Angka yang diikuti huruf yang sama tidak berbeda nyata pada uji lanjut BNT taraf 5\%, KK = koefisien keragaman 
Tabel 6. Keragaan hasil dan komponen hasil 10 galur/varietas di lahan rawa lebak pada percobaan petani (baby trial), Desa Hambuku Raya, Kabupaten Hulu Sungai Utara, Provinsi Kalimantan Selatan, MH 2018/19

\begin{tabular}{llrcccccc}
\hline $\begin{array}{l}\text { No. } \\
\text { Petani }\end{array}$ & Genotipe & $\begin{array}{c}\text { Tinggi } \\
\text { tanaman } \\
(\mathrm{cm})\end{array}$ & $\begin{array}{c}\text { Jumlah } \\
\text { anakan }\end{array}$ & $\begin{array}{c}\text { Umur } \\
\text { panen } \\
(\mathrm{HST})\end{array}$ & $\begin{array}{c}\text { Panjang } \\
\text { malai } \\
(\mathrm{cm})\end{array}$ & $\begin{array}{c}\text { Bobot brangkasan } \\
\text { basah per rumpun } \\
(\mathrm{g})\end{array}$ & $\begin{array}{c}\text { Bobot brangkasan } \\
\text { kering per rumpun } \\
(\mathrm{g})\end{array}$ & $\begin{array}{c}\text { Hasil } \\
\left(\text { ton ha }{ }^{-1}\right)\end{array}$ \\
\hline 1 & Inpara 3 & 138.3 & 13 & 130 & 25.9 & 195.4 & 129.6 & 5.2 \\
2 & Inpara 8 & 135.3 & 20 & 116 & 24.5 & 304.1 & 172.2 & 6.9 \\
3 & Tapus & 128.7 & 9 & 112 & 26.5 & 183.4 & 121.6 & 4.8 \\
4 & Inpari 42 & 92.7 & 17 & 115 & 25.2 & 198.7 & 68.9 & 2.8 \\
5 & Inpari 22 & 107.0 & 21 & 115 & 23.5 & 190.7 & 72.5 & 2.9 \\
6 & Inpari 30 & 103.3 & 18 & 110 & 22.1 & 367.4 & 170.4 & 6.8 \\
7 & Inpari 43 & 106.7 & 14 & 112 & 19.2 & 175.6 & 89.6 & 3.6 \\
8 & IR11T230 & 113.7 & 25 & 114 & 21.9 & 267.0 & 83.0 & 3.3 \\
9 & B14366E-KY-3 & 120.7 & 15 & 118 & 23.9 & 166.0 & 124.4 & 5.0 \\
10 & B13926E-KA-1 & 111.0 & 14 & 115 & 24.9 & 118.8 & 60.6 & 2.5 \\
\hline
\end{tabular}

gabahnya yang kecil-kecil serupa varietas lokal Siam, vigor kokoh, jumlah anakan banyak, tanaman tidak terlalu tinggi dan malai panjang. Pilihan ketiga adalah Inpara 3 yang disukai oleh $36.7 \%$ responden. Inpara 3 diduga tidak terlalu disukai oleh tikus, malai panjang dan berada dibawah daun bendera sehingga aman dari serangan burung, gabah dan beras sesuai preferensi petani. Namun, Inpara 3 memiliki kelemahan yaitu tinggi dan umur yang terlalu dalam. Hal yang menarik bahwa Tapus dan Inpara 3 walaupun disukai oleh banyak responden, namun tidak menghasilkan bobot panen yang tinggi. Penelitian partisipatif yang dilakukan oleh Hairmansis et al. (2015) juga menjumpai hal yang serupa, bahwa tidak semua galur dengan nilai preferensi yang tinggi menghasilkan gabah yang tinggi, demikian juga sebaliknya tidak semua galur dengan hasil gabah lebih tinggi dari pembanding, mempunyai nilai preferensi yang tinggi atau disukai oleh petani. Hal ini mengindikasikan adanya kriteria spesifik yang menjadi perhatian petani, dan komponen hasil bukan merupakan satu-satunya penentu preferensi petani. Perbaikan terhadap karakter bobot hasil masih dapat dilakukan melalui pendekatan budidaya dan pengendalian hama dan penyakit secara komprehensif. Di lahan rawa lebak, peningkatan jumlah malai, berat gabah kering giling per rumpun dan berat gabah kering giling per petak varietas Inpara 3, dapat dilakukan melalui pemberian paket pemupukan dengan dosis hasil interpretasi PUTR, yaitu $300 \mathrm{~kg} \mathrm{ha}^{-1}$ urea $+50 \mathrm{~kg} \mathrm{ha}^{-1} \mathrm{SP}-36+150 \mathrm{~kg} \mathrm{ha}^{-1} \mathrm{KCl}$ (Rois et al., 2017).

Seleksi partisipatif memberikan timbal balik pada pemulia untuk memperbaiki varietas yang telah ada. Nilai preferensi positif mengindikasikan bahwa genotipe yang diujikan diterima oleh sebagian besar petani, sehingga genotipe terpilih diharapkan lebih diterima dan akan diadopsi oleh petani karena sifat-sifat yang dibawa telah sesuai dengan preferensi petani setempat. Pilihan petani yang beragam ini memberikan peluang terhadap peningkatan keragaman genetik di lapangan, sehingga performa dan ketahanan varietas ini terhadap hama dan penyakit menjadi

Tabel 7. Nilai preferensi (preference score), persentase suara suka dan hasil gabah galur/vareitas padi rawa di lahan rawa lebak tengahan di Desa Hambuku Raya, Kabupaten Hulu Sungai Utara, Provinsi Kalimantan Selatan, MH 2018/19

\begin{tabular}{|c|c|c|c|c|c|c|}
\hline No. & Galur/Varietas & $\begin{array}{l}\text { Jumlah suara } \\
\text { suka }\end{array}$ & $\begin{array}{c}\text { Jumlah suara } \\
\text { tidak suka }\end{array}$ & Nilai preferensi & $\begin{array}{c}\text { Persentase suara } \\
\text { suka }(\%)\end{array}$ & $\begin{array}{c}\text { Bobot hasil } \\
\left(\text { ton } \mathrm{ha}^{-1}\right)\end{array}$ \\
\hline 1 & Inpara 3 & 10 & 8 & 0.07 & 36.7 & 4.8 \\
\hline 2 & Inpara 8 & 17 & 5 & 0.40 & 56.7 & 7.0 \\
\hline 3 & Tapus & 12 & 6 & 0.20 & 43.3 & 4.9 \\
\hline 4 & Inpari 42 & 1 & 9 & -0.27 & 3.3 & 5.3 \\
\hline 5 & Inpari 22 & 9 & 5 & 0.13 & 23.3 & 5.6 \\
\hline 6 & Inpari 30 & 2 & 8 & -0.20 & 6.7 & 5.8 \\
\hline 7 & Inpari 43 & 1 & 5 & -0.13 & 3.3 & 3.8 \\
\hline 8 & IR11T230 & 2 & 2 & 0.00 & 6.7 & 4.7 \\
\hline 9 & B14366E-KY-3 & 2 & 7 & -0.17 & 6.7 & 3.0 \\
\hline 10 & B13926E-KA-1 & 4 & 5 & -0.03 & 13.3 & 3.5 \\
\hline
\end{tabular}


lebih stabil. Ketiga varietas pilihan petani ini memiliki keragaman ketahanan terhadap hama dan penyakit (Sasmita et al., 2019; Ningsih, 2011). Varietas Tapus dilaporkan memiliki ketahanan terhadap hawar daun bakteri dan cukup tahan terhadap penggerek batang kuning (Ningsih, 2011). Varietas Inpara 3 tahan terhadap terhadap penyakit blas daun ras 101, 123, 141, 373 serta agak tahan wereng batang coklat biotipe 3. Sedangkan Inpara 8 Agritan tahan terhadap hawa daun bakteri patotipe III, agak tahan terhadap hawa daun bakteri patotipe IV dan VIII serta agak tahan terhadap blas ras 133 (Sasmita et al., 2019). Keragaman genetik terhadap hama dan penyakit khususnya terhadap blas daun sangat diperlukan untuk mengatasi serangan di lapangan. Gallet et al. (2014) menyampaikan bahwa difusi varietas di lapangan merupakan salah satu strategi yang menjanjikan untuk mengatasi serangan blas dan mempertahankan epidemik penyakit agar tetap berada pada level rendah dengan cara menghambat adaptasi patogen terhadap varietas tahan.

\section{Uji Preferensi Berdasarkan Kuisioner}

Uji preferensi menunjukkan 3 varietas disukai petani dengan nilai rataan tertinggi, yaitu Tapus, Inpara 3, dan Inpara 8 (Tabel 8). Hasil ini sejalan dengan penilaian petani melalui metode partisipatif (PVS), ketiga varietas tersebut menjadi pilihan petani namun berbeda urutan rankingnya.

Nilai rata-rata untuk masing-masing karakter menunjukkan bahwa vigor tanaman merupakan karakter yang utama yang digunakan para responden dalam menilai genotipe (Tabel 8), diikuti oleh karakter jumlah malai, warna gabah dan umur. Menurut para responden, vigor tanaman yang terlihat kokoh dengan jumlah anakan produktif, panjang malai dan jumlah gabah per malai yang banyak serta daun yang bersih dari hama dan penyakit menjadi kriteria penting dalam menentukan preferensi responden.

Vigor tanaman menunjukkan tingkat adaptasi genotipe terhadap lingkungan tumbuhnya. Inpara 3, Tapus dan Inpara 8 berturut-turut memiliki vigor yang disukai oleh responden, dengan nilai masing-masing sebesar 84.80 dan $77.30 \%$. Ketiga genotipe yang merupakan varietas unggul lahan rawa ini memiliki toleransi terhadap genangan dan keracunan besi yang menjadi faktor pembatas di lahan rawa. Di lokasi penelitian, ketiga genotipe toleran terhadap genangan dengan skor 1-3 (Tabel 5). Inpara 3 dilaporkan telah disukai oleh petani lahan rawa sejak dikenalkan pada tahun 2011, dan adopsinya oleh petani meningkat secara signifikan. Darsani dan Koesrini (2016) melaporkan bahwa Inpara 3 pertama ditanam di lahan seluas 86 ha pada 2011, dan meningkat menjadi $4827 \mathrm{Ha}$ pada tahun 2015. Inpara 8 Agritan juga dilaporkan disukai oleh petani etnis Banjar di Kabupaten Barito Kuala, dengan nilai preferensi tertinggi dibandingkan varietas lainnya (Darsani dan Koesrini, 2018). Inpara 8 Agritan memperoleh nilai preferensi $81.80 \%$ untuk pertumbuhan vegetatifnya dan $77.10 \%$ untuk keragaan tanaman saat generatif.

Jumlah anakan produktif merupakan karakter yang penting karena menentukan komponen hasil dan bobot panen yang dihasilkan oleh suatu varietas atau galur. Beberapa karakter yang berhubungan positif dan sangat erat dengan bobot hasil adalah luas daun $(\mathrm{r}=0.70)$, jumlah anakan $(\mathrm{r}=$ $0.69)$, jumlah anakan produktif $(\mathrm{r}=0.76)$, dan jumlah gabah per malai $(\mathrm{r}=0.60)$ (Chozin dan Marwanto, 2013). Jumlah

Tabel 8. Preferensi petani terhadap morfologi tanaman dan gabah beberapa galur padi di lahan rawa lebak tengahan di Desa Hambuku Raya, Kabupaten Hulu Sungai Utara, Provinsi Kalimantan Selatan, MH 2018/19

\begin{tabular}{|c|c|c|c|c|c|c|c|c|c|c|c|c|}
\hline \multirow[b]{2}{*}{ Varietas } & \multicolumn{12}{|c|}{ Preferensi responden $(\%)$} \\
\hline & $\begin{array}{c}\text { Tipe } \\
\text { tanaman }\end{array}$ & $\begin{array}{l}\text { Tinggi } \\
\text { tanaman } \\
(\mathrm{cm})\end{array}$ & $\begin{array}{c}\text { Jumlah } \\
\text { anakan } \\
\text { produktif }\end{array}$ & $\begin{array}{c}\text { Bentuk } \\
\text { gabah }\end{array}$ & $\begin{array}{l}\text { Ukuran } \\
\text { gabah }\end{array}$ & $\begin{array}{l}\text { Warna } \\
\text { gabah }\end{array}$ & $\begin{array}{c}\text { Serangan } \\
\text { hama \& } \\
\text { penyakit }\end{array}$ & $\begin{array}{l}\text { Toleransi } \\
\text { cekaman } \\
\text { genangan }\end{array}$ & $\begin{array}{c}\text { Umur } \\
\text { tanaman }\end{array}$ & $\begin{array}{c}\text { Vigor } \\
\text { tanaman }\end{array}$ & $\begin{array}{c}\text { Rataan } \\
\text { Varietas/ } \\
\text { Galur }\end{array}$ & Kriteria \\
\hline Inpara 3 & 78.7 & 74 & 79.3 & 78.7 & 76.0 & 80.0 & 68.7 & 74.0 & 74.0 & 84.0 & 77.0 & Suka \\
\hline Inpara 8 & 72.7 & 70.7 & 78.0 & 76.0 & 75.3 & 74.7 & 66.7 & 81.3 & 76.0 & 77.3 & 74.1 & Suka \\
\hline Tapus & 82.0 & 78.7 & 81.3 & 76.0 & 80.0 & 80.0 & 73.3 & 82.0 & 76.7 & 80.0 & 78.7 & Suka \\
\hline Inpari 42 & 68.7 & 69.3 & 69.3 & 70.0 & 69.3 & 72.0 & 61.3 & 68.7 & 71.3 & 69.3 & 69.0 & Suka \\
\hline Inpari 22 & 74.7 & 72.0 & 73.3 & 76.0 & 76.7 & 76.7 & 65.3 & 63.3 & 78.0 & 77.3 & 74.4 & Suka \\
\hline Inpari 30 & 66.0 & 66.7 & 66.7 & 68.7 & 66.0 & 66.7 & 53.3 & 77.2 & 68.7 & 68.0 & 65.6 & $\begin{array}{c}\text { Cukup } \\
\text { suka }\end{array}$ \\
\hline Inpari 43 & 75.9 & 74.0 & 77.2 & 71.8 & 72.6 & 75.3 & 67.2 & 82.0 & 72.6 & 78.9 & 73.9 & Suka \\
\hline IR11T230 & 61.3 & 62.0 & 63.3 & 62.7 & 58.0 & 60.0 & 51.3 & 80.3 & 61.3 & 62.7 & 60.3 & $\begin{array}{c}\text { Cukup } \\
\text { suka }\end{array}$ \\
\hline $\begin{array}{l}\text { B14366E- } \\
\text { KY-3 }\end{array}$ & 56.7 & 55.3 & 65.3 & 64.0 & 64.0 & 64.7 & 49.3 & 78.7 & 65.3 & 64.7 & 61.0 & $\begin{array}{c}\text { Cukup } \\
\text { suka }\end{array}$ \\
\hline $\begin{array}{l}\text { B13926E- } \\
\text { KA-1 }\end{array}$ & 56.7 & 55.3 & 65.3 & 64.0 & 64.0 & 64.7 & 49.3 & 76.7 & 65.3 & 64.7 & 61.0 & $\begin{array}{c}\text { Cukup } \\
\text { suka }\end{array}$ \\
\hline $\begin{array}{l}\text { Rataan } \\
\text { Karakter }\end{array}$ & 69.3 & 67.8 & 71.9 & 70.8 & 70.2 & 71.5 & 60.6 & 76.4 & 70.9 & 72.7 & & \\
\hline
\end{tabular}

Keterangan: Skor 52.01-68\% = cukup suka $(\mathrm{CS}), 68.01-84 \%=$ suka $(\mathrm{S}), 84.01-100 \%=$ sangat suka $(\mathrm{SS})$ 
anakan berkorelasi erat dengan hasil berasal dari efek tak langsung melalui jumlah anakan produktif. Jumlah anakan yang banyak mengindikasikan tersedianya fungsi biomasa (daun dan batang) sebagai source yang menghasilkan asimilat sebagai cadangan makanan untuk pembentukan malai dan pengisian gabah.

Hal yang unik bahwa warna gabah menjadi salah satu fokus responden dalam menilai suatu varietas. Hasil serupa dilaporkan oleh Darsani dan Koesrini (2018) dimana warna gabah Inpara 3 dan 8 Agritan termasuk kategori disukai oleh para petani etnis Jawa maupun Banjar. Responden menyukai warnah gabah yang kuning bersih, tidak kusam, seragam dan tidak ada bercak. Hal ini sangat dimengerti, karena blas daun yang disebabkan oleh cendawan merupakan penyakit utama di lahan rawa lebak tengahan. Cendawan dapat menyebabkan perubahan warna gabah menjadi kusam atau kotor (Ashfaq et al., 2017), sehingga responden sangat fokus terhadap warna gabah dan menjadikannya salah satu kriteria penting dalam penilaian varietas. Bentuk gabah juga menjadi kriteria penilaian responden, diindikasikan dengan tingginya nilai preferensi pada karakter ini (Tabel 8). Bentuk gabah yang disukai petani adalah bentuk yang ramping hingga medium dan bernas. Varietas Inpara 3, Inpara 8, Tapus, dan Inpari 22 merupakan varietas yang disukai karena bentuk gabahnya.

Kriteria penting terakhir pada penilaian oleh responden adalah umur tanaman. Responden menyukai umur varietas Inpara 8, Tapus dan Inpari 22, diindikasikan oleh nilai preferensi yang tinggi pada ketiga varietas untuk karakter umur tanaman. Umur tanaman yang genjah disukai oleh responden karena pola tanam di lahan rawa lebak tengahan yang dimulai pada akhir musim hujan. Untuk menghindari kekurangan air dan kekeringan, maka diperlukan varietasvarietas yang genjah.

\section{KESIMPULAN}

Produktivitas genotipe yang ditanam di percobaan induk lebih baik dibandingkan di percobaan anak. Inpara 8 merupakan genotipe dengan produktivitas tertinggi baik di percobaan induk maupun percobaan anak. Terdapat tiga genotipe yang disukai oleh responden, yaitu Inpara 3, Tapus dan Inpara 8 Agritan. Vigor tanaman, jumlah anakan produktif, bentuk dan warna gabah dan umur tanaman, merupakan karakter menjadi fokus penilaian petani terhadap genotipe baru. Penilaian varietas dan galur dapat dilakukan melalui kuisioner maupun seleksi partisipatif.

\section{UCAPAN TERIMA KASIH}

Penulis mengucapkan terima kasih kepada Badan Penelitian dan Pengembangan Pertanian atas bantuan dana penelitian melalui Kerja Sama Penelitian, Pengkajian, dan Pengembangan Pertanian Strategis (KP4S) No. 358.2/ PL.040/H.1/05/2018.K di Balai Penelitian Pertanian Lahan Rawa untuk Ir. Hendri Sosiawan, CESA. Pada kesempatan ini, penulis juga mengucapkan terima kasih kepada semua pihak yang telah membantu dalam pelaksanaan kegiatan penelitian dan penulisan karya tulis ini.

\section{DAFTAR PUSTAKA}

[BPS] Badan Pusat Statistika. 2019. Statistika daerah Kabupaten Hulu Sungai Utara 2019. https:// hulusungaiutarakab.bps.go.id [30 Juli 2020].

[BPS] Badan Pusat Statistika. 2020. Kabupaten Hulu Sungai Utara dalam angka 2020. https://hulusungaiutarakab. bps.go.id/ [30 Juli 2020].

Aristya, V.E. 2017. Menuju mandiri benih padi lokal melalui pemuliaan partisipatif. Warta Inovasi 10:35-38.

Ashfaq, M., U. Mubashar, M.S. Haider, M. Ali, A. Ali, M. Sajjad. 2017. Grain discoloration: an emerging threat to rice crop in Pakistan. J. Anim. Plant Sci. 27:696707.

Bhatta, M.R., J. Tripathi, S.U. Khan, D. Bhandari, A.P. Regmi, G.S. Giri, B.R. Thapa, N.R. Gautam, H.K. Chaudhary, A. Rauf, G.O. Ferrara, S. Justice. 2006. Participatory varietal selection for enhancing yield and varietal diversity: A case study in wheat PVS in Rupandehi District. Paper presented at Regional Participatory Wheat Research Workshop Jointly Organized by Banaras Hindu University (BHU), U.P., India, CAZS-Natural Resources, University of Wales, UK and International Maize and Wheat Improvement Centre (CIMMYT), 10-14 February, Varanasi, India.

Dariah, A., S. Nurzakiah, F. Agus. 2013. Proses emisi serta inovasi teknologi adaptasi dan mitigasi emisi GRK di lahan gambut. In Haryono, E. Pasandaran, M. Syarwani, Ai Darihan, S.M. Pasaribu, N. Sutrisno Saad (Eds.). Politik Pembangunan Pertanian Menghadapi Perubahan Iklim. Badan Litbang Pertanian. Kementerian Pertanian. IAARD Press. Jakarta.

Darsani, R.Y., Koesrini. 2016. Tingkat adopsi varietas Inpara dan Margasari di lahan rawa pasang surut. J. Agros 18:65-80.

Darsani, R.Y., Koesrini. 2018. Preferensi petani terhadap karakter beberapa varietas unggul padi lahan rawa pasang surut. J. Penelitian Pertanian Tanaman Pangan 2:85-94.

Gallet, R., F. Bonnot, J. Milazzo, C. Tertois, H. Adreit, V. Ravigné, D. Tharreau, E. Fournier. 2014. The variety mixture strategy assessed in a GXG experiment with rice and the blast fungus Magnaporthe oryzae. Frontiers in Genetics 4:1-11.

Hairmansis, A., Supartopo, Suwarno. 2015. Seleksi varietas partisipatif terhadap galur-galur elit padi gogo di lahan petani. Ilmu Pertanian 18:61-68. 
Koesrini, M. Saleh, S. Nurzakiah. 2017. Adaptabilitas varietas Inpara di lahan rawa pasang surut tipe luapan air B pada musim kemarau. J. Agron. Indonesia 45:117-123.

Koesrini, M. Saleh, M. Thamrin. 2018. Adaptasi agronomi padi unggul varietas Inpara pada lahan rawa pasang surut. J. Penelitian Pertanian Tanaman Pangan 2:7783.

Maftu'ah, E., W. Annisa, M. Noor. 2016. Teknologi Pengelolaan Lahan Rawa untuk Tanaman Pangan dan Hortikultura dalam Konteks Adaptasi Terhadap Perubahan Iklim. J. Sumberdaya Lahan 10:103-114.

Manzanilla, D.O., T.R. Paris, G.V. Vergara, A.M. Ismail, S. Pandey, R.V. Labios, G.T. Tatlonghari, R.D. Acda, T.T.N. Chi, K. Duoangsila, I. Siliphouthone, M.O.A. Manikmas, D.J. Mackill. 2011. Submergence risks and farmers' preferences: Implications for breeding Sub1 rice in Southeast Asia. Agric. Sys. 104:335347.

Ningsih, R.D. 2011. Deskripsi sederhana varietas padi Tahun 1978-2010. Balai Pengkajian Teknologi Pertanian Kalimantan Selatan.

Noor, M., N. Sutrisno, H. Sosiawan. 2019. Manajemen air di lahan rawa berbasis mini-polder dalam mendukung pengembangan pertanian modern. Hal. 235-268. Dalam Djufry, F., E. Pasandaran, B. Irawan, M. Ariani (Eds.). Manajemen sumber daya alam dan produksi mendukung pertanian modern. IPB Press.

Peng, S., 2017. Booming research on rice physiology and management in China: A bibliometric analysis based on three major agronomic journals. J. Integr. Agric. 16:2726-2735.

Rois, A.S., Z. Basri. 2017. Uji adaptasi padi unggul Inpara3 di lahan rawa lebak menggunakan berbagai paket pemupukan adaptif. J. Agroland 24:237-241.

Rumanti, I.A., Y. Nugraha, R.H. Wening, Z.J.C. Gonzaga, Suwarno, A. Nasution, D. Kusdiaman, E.M.
Septiningsih. 2016. Development of high-yielding rice varieties suitable for swampy lands in Indonesia. Plant Breed. Biotech. 4:413-425.

Sitaresmi, T., W.B. Suwarno, I.A. Rumanti, S.W. Ardie, H. Aswidinnoor. 2019. Parameters and secondary characters for selection of tolerance rice varieties under stagnant flooding condition. AGRIVITA J. Agric. Sci. 41:372-384.

Sasmita, P., Satoto, Rahmini, N. Agustiani, D.D. Handoko, Suprihanto, A. Guswara, Suharna. 2019. Deskripsi Varietas Unggul Baru Padi. Badan Penelitian dan Pengembangan Pertanian.

Shelton, A.C., W.F. Tracy. 2016. Participatory plant breeding and organic agriculture: A synergistic model for organic variety development in the United States. Elementa: Science of the Anthropocene 4:1-12.

Singh, S., D. Mackill, A.M. Ismail. 2013. Responses of SUB1 rice introgression lines to submergence in the field: yield and grain quality. Field Crops Res. 113:12-17.

Trinugroho, M.W., Mawardi. 2017. Pemantauan area genangan air pada rawa lebak menggunakan teknologi penginderaan jauh. J. Ilmiah Geomatika 23:49-56.

Waluyo, Suparwoto, Sudaryanto. 2008. Fluktuasi genangan air lahan rawa lebak dan manfaatnya bagi bidang pertanian di ogan komering ilir. J. Hidrosfir Indonesia 3:57-66.

Wahyuti, T.B., B.S. Purwoko, A. Junaedi, Sugiyanta, Abdullah, B. 2013. Hubungan Karakter Daun dengan Hasil Padi Varietas Unggul. J. Agron. Indonesia 41:181-187.

Wening, R.H., I.A. Rumanti, B.S. Purwoko, W.B. Suwarno, N. Khumaida. 2019. Screening of submergence tolerant rice under artificial condition based on multiple selection indices. Plant Breed. Biotech. 7:360-374. 